\title{
Physical, chemical and texture characteristics of Aro cheese
}

\author{
${ }^{1 *}$ González, M.L., ${ }^{1}$ Sánchez, H.C., ${ }^{2}$ Franco, F.M.J., ${ }^{2}$ Güemes, V.N. and ${ }^{2}$ Soto, S.S. \\ ${ }^{1}$ Universidad de la Cañada. Cuerpo Académico Aprovechamiento Integral de Productos Agroindustriales. \\ Carr. Teotitlán-San Antonio Nanahuatipán Km. 1.7 s/n. Paraje Titlacuatitla. Teotitlán de Flores Magón, \\ Oaxaca, México. C.P. 68540 \\ ${ }^{2}$ Universidad Autónoma del Estado de Hidalgo, Instituto de Ciencias Agropecuarias, Rancho Universitario, \\ Tulancingo, Hidalgo, México. C.P. 43600
}

\section{Article history:}

Received: 24 August 2017 Received in revised form: 26 September 2017

Accepted: 28 September 2017 Available Online: 4 October 2017

\section{Keywords:}

Fresh cheese,

Artisanal cheese,

Enzymatic coagulation

\section{DOI:}

https://doi.org/10.26656/fr.2017.2(1).211

\begin{abstract}
In 2016, Mexico's total annual production of cheese was 375,181 tons. Cheese is widely consumed among all socioeconomic groups, and the decision to purchase this product is based on income, with a wide variety of cheeses, brands, and styles available. The fresco cheese is the most popular type and is mostly produced according to traditional or artisanal methods in small family businesses, and small and medium-sized enterprises. It is made with the milk of the producers' livestock, giving it an added value. In Mexico, however, there is not enough scientific information related to the characterization of various dairy products of artisanal production, for example, Aro cheese. The aim of the present study was to define the physical, chemical, and rheological characteristics of the Aro cheese that is commercialized in Teotitlán de Flores Magón, Oaxaca, Mexico. Twenty-four samples of Aro cheese were collected in four establishments with high sales in Teotitlán de Flores Magón, Oaxaca, for analysis physical (Diameter, weight, height and color), chemical ( $\mathrm{pH}$, acidity, aw, chlorides, moisture, ashes, protein and fat), and texture (hardness, springiness, adhesiveness and cohesiveness). No difference was found in weight, diameter, height, and color $\left(L^{*}\right.$ and $\left.b^{*}\right)$. However, differences in hardness and cohesiveness were found. Although Aro cheese is characterized as an enzymatically coagulated cheese, $\mathrm{pH}$ values of 5.82 to 6.08 were recorded, and the data relating to moisture, protein, fat, and chlorides are similar to other Mexican fresh cheeses. The cheese of Aro that is commercialized in Teotitlán de Flores Magón, presents similar physical, chemical and texture characteristics to other fresh cheeses of artisanal production.
\end{abstract}

\section{Introduction}

Cheese is defined as a product made from standardized and pasteurized milk curd from cows or other animal species, with or without the addition of cream, obtained by the coagulation of casein with rennet, with or without further treatment by heating, draining, pressed or not pressed, with or without addition of ripening yeasts and optional edible ingredients, giving rise to different varieties such as fresh, matured and processed cheeses (NOM, 2010). Included within the range of fresh cheeses are Frescal cheese, cooked cheese, and acidified cheese, all of which are characterized by their high moisture content, mild taste, lack of rind, and short shelf life of no more than 10 days (Villegas and Cervantes, 2011). According to Hnosko et al. (2009), a fresh cheese is defined as "a soft, high moisture cheese made in North, Central or South America, and may have different names depending on the country, state or region". Generally, they have the following characteristics: Moisture content from $46 \%$ to $57 \%$, protein content from $15 \%$ to $21 \%$, fat content from $20 \%$ to $29 \%$, salt content from 1 to $3 \%$ and $\mathrm{pH}$ from 5.3 to 6.5 (Hwang and Gunasekaran, 2001; Tunick and Van Hekken, 2010). They are made with pasteurized whole milk or milk with $2 \%$ fat, mesophilic lactic acid bacteria $(0.25 \%)$ and chymosin $(0.02 \%)$ with mild agitation. They have a mild taste, similar to that of fresh milk, and are sometimes slightly salty. The curd is usually ground before salting to improve friability, or before mixing (Guo et al., 2011). The cheeses are placed in round 
molds for 16 hours, and the final $\mathrm{pH}$ is between 5.2 to 5.7 (Hnosko et al., 2009).

The texture, color, melting, and gratin of the cheese are mainly due to their physical and chemical properties, which allow for the classification of different types of cheeses. In addition, they are related due to the interaction of casein molecules (Lucey et al., 2003; Solís et al., 2013). On the other hand, the physical characteristics of cheese, including flavor, depend on a number of factors, such as milk composition and quality, milk heat treatment, type of acidification (concentration and type of starter culture and coagulant agent), cheese composition (water, protein and fat), $\mathrm{pH}$ of the cheese, the content of calcium and other minerals, and the ripening conditions (curd size, curd time and cooking temperature, as well as temperature and relative humidity) (Gutierrez et al., 2013). In the United States of America, the physical and rheological properties of some cheeses are even more important than flavor attributes. In a Texture Profile Analysis (TPA), a food sample is compressed and decompressed twice, simulating the chewing of food. The results obtained give different texture notes which provide a strong correlation with those obtained by sensorial methods and is one of the most common tests for evaluating cheese texture (Gunasekaran and Ak, 2003; Bourne, 2004). The parameters most used for the TPA of cheese are hardness, springiness, adhesiveness, and fracturability (Hwang and Gunasekaran, 2001).

Mexican artisanal cheeses play an important role in the economy of small-scale dairy farmers in rural areas. These cheeses are of gastronomic and cultural importance, but very little is known about them and some are even unknown (Solís et al., 2013). It is for these reasons that the objective of this research is to describe the physical, chemical and texture characteristics of Aro cheese commercialized in the municipality of Teotitlán de Flores Magón, Oaxaca, Mexico.

\section{Materials and methods}

\subsection{Obtaining the samples}

The experiments were carried out in the Biology Laboratory of the Universidad de la Cañada as well as the Food Science and Technology Research Center Laboratories and the Food Technology Laboratory at the Institute of Agricultural Sciences at the Universidad Autónoma del Estado de Hidalgo. The sample size and frequency of Aro cheese sampling (unpublished data) were determined using a market study, which included a survey.

Four establishments (which between them accounted for $50 \%$ of total Aro cheese sales) were selected, and three samples were taken every week from each establishment during the months of April, May and June 2015. The samples purchased had undergone one day of processing and were transported in refrigeration $\left(4^{\circ} \mathrm{C}\right)$ to the Biology Laboratory of the Universidad de la Cañada for analysis. Of the three Aro cheese samples purchased each week, one sample was used for physical analysis (diameter, height, weight, and shape) and chemical analysis $(\mathrm{pH}$, acidity, humidity, ash, percentage of chlorides, fat, and protein). The second sample was used for color determination ( $L, a^{*}$, and $\left.b^{*}\right)$ and water activity, while the third sample was used for texture analysis (hardness, adhesiveness, cohesivity, and springiness). In Figure 1, a photograph of the studied of Aro cheese is shown.

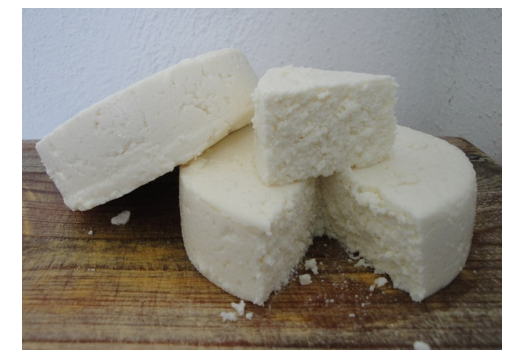

Figure 1. Photograph of Aro cheese

\subsection{Physical analysis of the Aro cheese}

The weight was determined using a digital weight scale (Sartorius, TE2145) and expressed in grams. A Vernier (Metromex, 222-8) was used to determine the diameter, height, and shape to the nearest $0.01 \mathrm{~mm}$.

\subsection{Chemical analysis of the Aro cheese}

$\mathrm{pH}$ was measured according to AOAC methods (2000), with some modifications. An amount of $50 \mathrm{~mL}$ of distilled water was added to a $10 \mathrm{~g}$ sample and homogenized using a Stomacher (80 Biomaster) so that a potentiometer Orion (Thermo Fisher Scientific, USA) could be used later. A $10 \mathrm{~mL}$ aliquot was taken from the homogenate to determine acidity (AOAC, 2000). The acidity was expressed as a percentage of lactic acid.

The determination of the color parameters was performed with a reflectance spectrophotometer (Minolta CM-508d, Tokyo, Japan), and the following values were determined: $L^{*}$ (Brightness), $a^{*}$ [red (-a) and green $(+a)$ indexes] and $b^{*}$ [yellow (-b) and blue $(+\mathrm{b})$ indexes]. The instrument was calibrated following the supplier's instructions, and measurements were made using a thin 
transparent plastic film (polyvinyl chloride) on the surface of the cheese.

Water activity was carried out using an Aqualab CX2 analyzer (Decagon Aqualab, Pullman, WA, USA). Approximately $3 \mathrm{~g}$ of homogeneous sample was deposited in a plastic cuvette and measurements were taken at a temperature of $22 \pm 2{ }^{\circ} \mathrm{C}$.

In order to determine the chlorides, specifically $\mathrm{NaCl}, 25 \mathrm{~mL}$ of $0.1 \mathrm{~N}$ silver nitrate and $25 \mathrm{~mL}$ of concentrated nitric acid was added to $2 \mathrm{~g}$ of cheese. The mixture was boiled for $1 \mathrm{~min}$, and $10 \mathrm{~mL}$ of a $10 \%$ of potassium permanganate was then added. This mixture was then boiled for a further $5 \mathrm{~min}$. An amount of $100 \mathrm{~mL}$ of distilled water was added as well as $5 \mathrm{~mL}$ of a solution of ferric sulphate ammonium pentahydrate (5\%). By titration with $0.1 \mathrm{~N}$ ammonium thiocyanate solution, the $\mathrm{NaCl}$ content was determined (Serres et al., 1973).

Determining the moisture content was performed according to AOAC methods. An amount of $3 \mathrm{~g}$ of cheese was placed in an aluminum tray of constant weight, and the drying of the sample was carried out at $105^{\circ} \mathrm{C}$ for 12 hours in a forced air convection oven (AOAC, 2000).

The ash content was performed according to Serres et al. (1973), using porcelain crucibles at constant weights, into which $3 \mathrm{~g}$ of cheese were placed. The cheese was calcined using a lighter until no smoke was present, and the crucibles were then placed in a muffle (Thermo scientific, ThermoLyne F60-18, U.S.A) at 550 $\mathrm{C}$ for 12 hours, until a white color appeared.

Determining the protein concentration was performed employing the Kjeldahl method according to the Mexican Standard, through use of a Büchi digester B -414 and a Büchi K-350 distillation unit. A factor of 6.38 was used to express the average nitrogen content as a percentage of protein (NMX, 1976).

The fat content was determined by the Gerber method using the Van Gulikbutyrometric, which consisted of digestion of the protein components with sulfuric acid and separation of the fat by centrifugation (Serres et al., 1973).

\subsection{Texture}

Determining the texture was performed using a TAHDi Universal Texturometer (Texture Technologies, New York, USA / Stable Micro Systems, Surrey, UK). Pieces of $1 \mathrm{~cm}^{3}$ cheese were placed into the instrument with a load cell of $50 \mathrm{~kg}$ and a speed of $1 \mathrm{~mm} / \mathrm{s}$ until the cheese was cut into smaller pieces. Only the maximum strength (hardness), springiness, adhesiveness, and cohesiveness were analyzed according to Szczesniak (1963, 1966), Bourne (1978) and Van (1991).

\subsection{Statistical analysis}

Data from physical, chemical and texture characteristics were subjected to one-way ANOVA, and pair-comparison of average achieved by Tukey's procedure at $P<0.05$, using statistical software SAS version 9.22 for Windows (SAS, 9.22, Institute Inc., Cary, NC, USA).

\section{Results and discussion}

In Table 1, the results of the physical parameters are shown for the Aro cheese samples. No significant difference $(\mathrm{p}>0.05)$ was found for diameter and height, due to the use of PVC (Polyvinyl chloride) molds, which are used to give the Aro cheese its unique shape and from which its name is derived. However, differences statistical results $(p>0.05)$ were found in the weight pieces of cheese the suppliers, with variation between 215-236g. The supplier 4 produced the heaviest cheeses, although there were no differences in diameter and height, this condition is due to the product of that supplier being more compact. This feature may negatively impact the sales revenue of this supplier because this cheese is usually sold per piece and not by weight.

Table 1. Physical characteristics of Aro cheese.

\begin{tabular}{cccc}
\hline POS & Weight $(\mathrm{g})$ & Diameter $(\mathrm{cm})$ & Height $(\mathrm{cm})$ \\
\hline 1 & $216.544 \pm 12.23^{\mathrm{a}}$ & $9.290 \pm 0.22^{\mathrm{a}}$ & $3.033 \pm 0.33^{\mathrm{a}}$ \\
2 & $215.418 \pm 10.04^{\mathrm{a}}$ & $9.127 \pm 0.23^{\mathrm{a}}$ & $3.112 \pm 0.13^{\mathrm{a}}$ \\
3 & $224.084 \pm 19.97^{\mathrm{ab}}$ & $9.499 \pm 0.46^{\mathrm{a}}$ & $3.186 \pm 0.11^{\mathrm{a}}$ \\
4 & $236.227 \pm 9.58^{\mathrm{b}}$ & $9.184 \pm 0.16^{\mathrm{a}}$ & $3.107 \pm 0.17^{\mathrm{a}}$ \\
\hline
\end{tabular}

POS: Point of Sale, ${ }^{\mathrm{a}, \mathrm{b}, \mathrm{c}}$ Columns with the same letter are not significantly different $(\mathrm{P}<0.05)$ using the Tukey average comparison test.

The results relating to the physical characteristics of Aro cheese commercialized in the municipality of Teotitlán coincide with the findings of López (2004) and González (2010), which stated that Aro cheese is a genuine Mexican cheese, known as molido (ground) cheese or fresh cheese with the following characteristics: cylindrical flat shape, weight of $250 \mathrm{~g}$ to $1 \mathrm{~kg}$, a fresh soft cheese, non-acidified and enzymatically coagulated. During production, the cheese paste is finely ground which results in a granular texture. The paste is then placed in Aro cheese specific molds of varying sizes and thickness. 
Table 2. pH, acidity, $\mathrm{a}_{\mathrm{w}}$ and color in Aro cheese samples.

\begin{tabular}{ccccccc}
\hline POS & $\mathrm{pH}$ & Acidity $(\%)$ & $\mathrm{a}_{\mathrm{w}}$ & $L^{*}$ & $a^{*}$ \\
\hline 1 & $5.93 \pm 0.18^{\mathrm{b}}$ & $0.80 \pm 0.16^{\mathrm{ab}}$ & $0.959 \pm 0.01^{\mathrm{a}}$ & $88.09 \pm 1.09^{\mathrm{a}}$ & $0.394 \pm 0.35^{\mathrm{a}}$ & $13.14 \pm 1.33^{\mathrm{a}}$ \\
2 & $5.82 \pm 0.25^{\mathrm{b}}$ & $0.92 \pm 0.34^{\mathrm{a}}$ & $0.951 \pm 0.01^{\mathrm{a}}$ & $89.041 \pm 0.87^{\mathrm{a}}$ & $-0.242 \pm 0.49^{\mathrm{b}}$ & $12.68 \pm 0.37^{\mathrm{a}}$ \\
3 & $6.08 \pm 0.27^{\mathrm{ab}}$ & $0.53 \pm 0.17^{\mathrm{bc}}$ & $0.955 \pm 0.01^{\mathrm{a}}$ & $88.86 \pm 0.78^{\mathrm{a}}$ & $0.268 \pm 0.29^{\mathrm{a}}$ & $12.84 \pm 1.73^{\mathrm{a}}$ \\
4 & $6.28 \pm 0.22^{\mathrm{a}}$ & $0.50 \pm 0.18^{\mathrm{c}}$ & $0.957 \pm 0.005^{\mathrm{a}}$ & $88.45 \pm 0.69^{\mathrm{a}}$ & $-0.450 \pm 0.20^{\mathrm{b}}$ & $12.21 \pm 0.78^{\mathrm{a}}$ \\
\hline
\end{tabular}

POS: Point of Sale, ${ }^{\text {a, b, c }}{ }^{2}$ Columns with the same letter are not significantly different $(\mathrm{P}<0.05)$ using the Tukey average comparison test.

It's presented in Table 2, the results for $\mathrm{pH}$, acidity, water activity and color $\left(L^{*}, a^{*}\right.$ and $\left.b^{*}\right)$. As previously stated, Aro cheese is a fresh, enzymatically coagulated cheese, therefore its $\mathrm{pH}$ should be similar to or close to that of fresh milk (6.6 to 6.8). However, our analysis shows that the Aro cheese of the Teotitlán region has a higher $\mathrm{pH}$ range, between 5.8 and 6.2, which is not usual for this type of cheese, and could be due to the development of a lactic-acid-producing microbiota, either in the milk or cheese.

In recent studies, Caro et al. (2014) reported $\mathrm{pH}$ values of $6.12 \pm 0.41$ in samples of Panela cheese, similar to the $\mathrm{pH}$ levels found for Aro cheese in our study. It should be noted that Panela cheese is widely distributed in Mexico and is popular among consumers. It is considered a healthy cheese because of its low-fat content, but its high moisture content (53 to 58\%) makes it highly perishable (González et al., 2016). The pH values decrease during maturation due to the presence of bacteria (mainly lactic acid bacteria) that resist pasteurization or contaminating bacteria after pasteurization (Guo et al., 2011).

The acidity of the Aro cheese was 0.5 to 0.92 , being microorganisms resistant to pasteurization or contaminates during storage and distribution. Vasek et al. (2013) and Longaray et al. (2012) reported acidity values similar to those found in our study $(0.75 \%$ and 0.23 to $0.89 \%$ respectively), in artisanal cheeses from Corrientes, Argentina, and in Serrano cheese (a traditional cheese from southern Brazil), emphasizing that this acidity level is normal in fresh cheeses or those with a short maturation period. González (2010) characterized fresh cheese made with unpasteurized milk (made according to artisanal methods in the municipality of Minatitlán, Veracruz, Mexico), and reported similar results to our study with maximum acidity values of 0.846 , with lactic acid as the main acid. The acidity of the cheese may increase during storage due to the presence of microorganisms, either starter cultures or microorganisms typically found in unpasteurized milk used to make cheese (Pinho et al., 2004).

The water activity found in Aro cheese was 0.950 to
0.96 (Table 2), which is characteristic of fresh cheeses. It could also favor microbial development, and shelf life would, therefore, be affected. With $\mathrm{a}_{\mathrm{w}}$ and $\mathrm{pH}$ values such as these, a large number of bacteria could develop, including pathogens. Several studies on fresh cheeses report values similar to or greater than the values in our study, such as Mexican cheeses with $\mathrm{a}_{\mathrm{w}}$ values of 0.963 to 0.988 (Caro et al., 2014), fresh unripened cheese with different salt concentrations with $\mathrm{a}_{\mathrm{w}}$ from 0.967 to 0.98 (Guo et al., 2011), traditional unripened Brazilian cheese with $\mathrm{a}_{\mathrm{w}}$ from 0.98 to 0.99 (Lima et al., 2008), and unripened Terrincho cheese with $a_{w}$ from 0.957 to 0.974 (Pinho et al., 2004). It should be mentioned that all these authors agree that the $\mathrm{a}_{\mathrm{w}}$ decreases during the maturation process, inhibiting different microorganisms, including pathogens.

The white color of milk is the result of the dispersion of visible light by the casein micelles, the globules of fat, as well as its coloring (carotene content). The homogenization of milk results in a whiter product due to increased dispersed light by smaller fat globules (Carpino et al., 2004; Fox et al., 2015). No significant difference was observed for the $L^{*}$ and $b^{*}$ values, as Aro cheese is very bright and yellow. These results are similar to those reported by Caro et al. (2014) for Panela cheese which, as already mentioned, is similar to Aro cheese. However, differences were found for the values in $a^{*}$, meaning that the Aro cheeses from point of sale (POS) 2 and 4 had a slight green coloring. It is worth mentioning that the cheeses from these two POS are those that had a highest moisture content, and Fox et al. (2015) mentions that the serum phase of the milk results in a green coloring due to the presence of riboflavin which is responsible for the coloring of whey.

The proximate composition of the Aro cheese is shown in Table 3. The results in the four POS varied, for the moisture content (59.04 to 63.67\%), fat content (7.17 to $17.58 \%$ ), protein content (14.04 to $16.91 \%$ ), ash content (4.17 to $5.29 \%$ ) and chloride content (3.57 to $3.97 \%$ ). As can be seen in Table 3, Aro cheese has high moisture content, and as such can be classified as a tender or soft cheese. It is also very susceptible to 
Table 3. Proximate composition of Aro cheese expressed as a percentage.

\begin{tabular}{cccccc}
\hline POS & Moisture & Fat & Protein & Ash & Chlorides \\
\hline 1 & $59.04 \pm 2.41^{\mathrm{b}}$ & $17.58 \pm 1.46^{\mathrm{a}}$ & $16.36 \pm 0.19^{\mathrm{a}}$ & $4.38 \pm 0.18^{\mathrm{b}}$ & $3.97 \pm 0.28^{\mathrm{a}}$ \\
2 & $63.67 \pm 1.90^{\mathrm{a}}$ & $11.92 \pm 5.07^{\mathrm{b}}$ & $16.91 \pm 0.85^{\mathrm{a}}$ & $5.29 \pm 0.51^{\mathrm{a}}$ & $3.75 \pm 0.63^{\mathrm{a}}$ \\
3 & $60.49 \pm 0.89^{\mathrm{b}}$ & $17.33 \pm 2.26^{\mathrm{a}}$ & $15.56 \pm 0.93^{\mathrm{ab}}$ & $4.17 \pm 0.45^{\mathrm{b}}$ & $3.99 \pm 0.53^{\mathrm{a}}$ \\
4 & $63.16 \pm 0.70^{\mathrm{a}}$ & $7.17 \pm 0.21^{\mathrm{c}}$ & $14.04 \pm 0.23^{\mathrm{b}}$ & $4.84 \pm 0.84^{\mathrm{ab}}$ & $3.57 \pm 0.58^{\mathrm{a}}$ \\
\hline
\end{tabular}

POS: Point of Sale, ${ }^{\mathrm{a}, \mathrm{b}, \mathrm{c}}$ Columns with the same letter are not significantly different $(\mathrm{P}<0.05)$ using the Tukey average comparison test.

Table 4. Texture Profile Analysis of Aro cheese samples.

\begin{tabular}{cccccc}
\hline POS & Hardness $(\mathrm{N})$ & Springiness $(\mathrm{mm})$ & Cohesiveness & Adhesiveness (N.s) & Resilience \\
\hline 1 & $7.259 \pm 0.45^{\mathrm{a}}$ & $0.854 \pm 0.01^{\mathrm{a}}$ & $0.664 \pm 0.01^{\mathrm{a}}$ & $-2.553 \pm 4.09^{\mathrm{a}}$ & $0.450 \pm 0.01^{\mathrm{a}}$ \\
2 & $15.185 \pm 0.80^{\mathrm{c}}$ & $0.847 \pm 0.003^{\mathrm{a}}$ & $0.566 \pm 0.04^{\mathrm{b}}$ & $-3.453 \pm 8.17^{\mathrm{a}}$ & $0.383 \pm 80.02^{\mathrm{a}}$ \\
3 & $15.130 \pm 1.27^{\mathrm{c}}$ & $0.944 \pm 0.009^{\mathrm{b}}$ & $0.429 \pm 0.03^{\mathrm{c}}$ & $-8.978 \pm 23.89^{\mathrm{a}}$ & $0.488 \pm 0,04^{\mathrm{a}}$ \\
4 & $9.755 \pm 0.38^{\mathrm{b}}$ & $0.871 \pm 0.03^{\mathrm{a}}$ & $0.474 \pm 0.03^{\mathrm{c}}$ & $-28.878 \pm 7.70^{\mathrm{a}}$ & $0.416 \pm 0.10^{\mathrm{a}}$ \\
\hline
\end{tabular}

POS: Point of Sale, ${ }^{a, b, c}$ Columns with the same letter are not significantly different $(\mathrm{P}<0.05)$ using the Tukey average comparison test.

various changes caused by the development of microorganisms, mainly by mesophiles and coliforms (Longaray et al., 2012). There are several studies on the chemical characterization of fresh cheese and Mexican cheeses with moisture results similar to ours; Kashar fresh cheese with moisture content of 54.7\% (Eroglu et al., 2016); Several Mexican cheeses, including Panela, Oaxaca, Tenate, Manchego, among others, with moisture content of 40.3 to $54.3 \%$ (Caro et al., 2014); Ranchero artisanal cheese with moisture content of 50.4 to $53.8 \%$ (Solís et al., 2013); Fresh cheese with moisture content of 50.6 to $55.63 \%$ (Gutiérrez et al., 2013). In general, these authors agree that the moisture content is related to the shelf life of the cheese and that during the manufacturing process, good manufacturing practice must be applied to reduce all risks of contamination. However, some of these cheeses are made according to artisanal methods.

The fat and protein content shows significant differences between some of the cheeses from the four POS, this variation, however, could be directly related to the quality of the milk, and this, in turn, depends on several factors, such as the breed of cattle, type of feeding (grazing, stabled or mixed), diet supplementation, and the cattle's health. As previously stated, the fat content can affect the color of the cheese (depending on the time of year, composition and type of feed, as well as lactation), and also has an effect on texture parameters. The lowest fat and protein percentage values (7.14 and 14.04 respectively) were found in cheese from POS 4, as well as having high moisture content. The results of the fat and protein content found in our research were lower than those reported by Eroglu et al. (2016), Caro et al. (2014), Solís et al. (2013), Gutiérrez et al. (2013), Longaray et al. (2012), Guerra et al. (2012) and Guo et al. (2011).

No significant difference was found for chloride content in Aro cheese from different POS. This could indicate that Aro cheese producers have well established or standardized amount of salt for the production process. However, there were significant differences in the ash content in the Aro cheeses of POS 2.Additionally, ash content is related to the moisture content of the product, water activity, and texture. Eroglu et al. (2016), report an average ash content of $3.56 \%$ in Kashar fresh cheese and mention that during maturation the ash increases and may have an effect on some unwanted microorganisms. Less than $2 \%$ of cheese salt is not sufficient to inhibit the growth of Enterobacteriaceae (Longaray et al., 2012). Khosrowshahi et al. (2006) reported 5.21\% ash content in Irani white cheese with 7 days of ripening, which affects the texture and conservation. Caro et al. (2014) reported a maximum of $3.95 \%$ ash content in Tenate cheese and lower values in different Mexican fresh cheeses, including the Panela variety. These values are lower than the values recorded for this paper.

Table 4 provides the results of the texture profile analysis. There are some significant differences in hardness in cheeses from some POS, with a range of 7.26 to $15.18 \mathrm{~N}$, indicating that Aro cheese is a soft cheese. The only major difference in springiness was cheese from POS 3, with the highest value of 0.944 , which could indicate that Aro cheese is a soft cheese (as suggested by the hardness values), with a fragile and brittle composition. For cohesiveness, values of 0.429 to 
0.664 were recorded in the cheeses from the different POS. This indicates a cohesive cheese with a higher chance of collapse of disintegration occurring. It is noteworthy to mention that low values were obtained in adhesiveness (-28.87 to -2.55 N.s), and no significant differences were found in all POS, therefore when consumed it is not going to adhere to the palate. There was no significant difference in resilience at all points of sale. Solís et al. (2013) mention that Ranchero artisanal cheese has an average hardness of $24.6 \mathrm{~N}$, classifying it as a soft cheese. In addition, they state that the firmness and/or hardness of the cheese depend on three factors: moisture, fat and mineral content. Due to the high content of water or fat, the protein molecules separated from the cheese which increased softness. The springiness $(0.86 \mathrm{~mm})$ means that the cheeses are softer, less fragile and brittle, but more resistant to deformation. The cohesiveness values of less than 0.59 suggest cheeses of low cohesion with a tendency to crumble and disintegrate, which in turn is directly related to the fat content.

There are several studies on texture properties in different types of cheese: fresh, ripened, different concentrations of fat during maturation, salt, and cheeses produced during different seasons of the year, type of feed, breed of cattle. However, most of these papers highlight that the content of fat, moisture, ash and $\mathrm{pH}$ have a direct influence on texture. For example, Solís et al. (2013) emphasized that the chemical composition of cheese is directly related to the texture profile, with the amount of salt being the most influential. Gutiérrez et al. (2013) mentioned that the texture differences between fresh cheese and Chihuahua cheese are moisture content as well fat content. Osorio et al. (2005) stated that the textural parameters of Edam cheese are highly dependent on the maturation level of the cheese. In general, Mexican cheeses have highly variable and different textures, as there are many differences in their composition, moisture content, $\mathrm{pH}$ and salt content, all of which have a direct effect on texture (Caro et al., 2014). Although Panela cheese is a fresh cheese, significant changes in its composition and texture occur during 15 days of storage (Guerra et al., 2012). Fresh cheeses with high moisture content have greater cohesiveness and lower hardness values (Tunick and Van Hekken, 2010). The texture of cheese depends on the protein matrix of casein, as well as the moisture and fat content. Less fat affects the firmness, adhesiveness, fracture strength, deformation, springiness, among other factors (Castro et al., 2014).

\section{Conclusion}

The Aro cheese commercialized in Teotitlán de Flores Magón, Oaxaca, Mexico, is considered a genuine fresh cheese from this region, with physical, chemical and texture characteristics very similar to other types fresh of cheese. The moisture, fat, protein and ash content directly affect texture the cheese's properties, such as hardness, elasticity, and cohesiveness, suggesting it is a soft, fragile and brittle cheese. The quality of the cheese is determined by the starting milk's chemical composition as well as the techniques used during processing since these directly influence the physical, chemical, optical and texture properties of Aro cheese.

\section{Acknowledgement}

The authors gratefully acknowledge Universidad de la Cañada for the financial support.

\section{References}

Association of Official Analytical Chemistry (AOAC). (2000). Official Methods of Analysis. $17^{\text {th }}$ ed. Washington, D.C: Association of Analytical Chemists, Inc.

Bourne, M.C. (1978). Texture profile analysis. Food Technology, 32(7), 62-66.

Bourne, M. (2004). Relation between texture and mastication. Journal of Texture Studies, 35, 125-143.

Caro, I., Soto, S., Fuentes, L., Gutiérrez, M.N., García, I.B., Monroy G.K.E. and Mateo, J. (2014). Compositional, functional and sensory characteristics of selected Mexican cheeses. Food and Nutrition Sciences, 5, 366-375.

Carpino, S., Home, J., Melilli, C., Licitra, G., Barbano D.M. and Van Soest, P.J. (2004). Contribution of native pasture to the sensory properties of Ragusano cheese. Journal of Dairy Science, 8(72), 308-315.

Castro, A.C., Novoa, C.F., Algecira, N. and Buitrago, G. (2014). Reología y textura de quesos bajos en grasa. Revista de Ciencia y Tecnología, 22, 58-66.

Eroglu, A., Toker, O.S. and Dogan, M. (2016). Changes in the texture, physicochemical properties and volatile compound profiles of fresh Kashar cheese ( $<90$ days) during ripening. International Journal of Dairy Technology, 69(2), 243-253.

Fox, P.F., Uniacke-Lowe, T., McSweeney, P.L.H. and O'Mahony J.A. (2015). Dairy Chemistry and Biochemistry. $2^{\text {nd }}$ ed. New York: Springer.

González, C.A.F., Yescas C., Ortiz E.A.M., De la Rosa, A.M.Á., Hernández M.A., and Vallejo, C.B. (2016). Invited review: Artisanal Mexican cheeses. Journal 
Dairy Science, 99(5), 3250-3262.

González, R.E.P. (2010). Caracterización de la composición físico química del queso fresco elaborado artesanalmente en Sehualaca, municipio de Minatitlán, Veracruz. Veracruz, México. Universidad Veracruzana, BSc. Thesis

Guerra, M.J.A., Montejano, J.G. and Martín, C.S.T. (2012). Evaluation of proteolytic and physicochemical changes during storage of fresh Panela cheese from Queretaro, Mexico and its impact in texture. CyTAJournal of Food, 10(4), 296-305.

Gunasekaran, S. and Ak, M.M. (2003). Cheese rheology and texture. 1st ed. New York: CRC Press.

Guo, L., Van Hekken, D.L., Tomasula, P.M., Shieh, J. and Tunick, M.H. (2011). Effect of salt on the chemical, functional, and rheological properties of Queso Fresco during storage. International Dairy Journal, 21, 352-357.

Gutiérrez, M.N., Trancoso, R. N. and Leal, R.M.Y. (2013). Texture profile analysis of fresh cheese and Chihuahua cheese using miniature cheese models. Tecnociencia Chihuahua, 7(2), 65-74.

Hnosko, J., Clark, S. and Van Hekken, D. (2009). Latin American cheeses. In Clark, S., Costello, M., Drake, M., and Bodyfelt, F. (Eds). The sensory evaluation of dairy products. $2^{\text {nd }}$ ed. New York: Springer.

Hwang, C.H. and Gunasekaran, S. (2001). Measuring crumbliness of some commercial Queso Fresco-type Latin American cheeses. Milchwissenschaft, 56, 446 -450 .

Khosrowshahi, A., Madadlou, A., Ebrahim, Z.M.M. and Emam, D.Z. (2006). Monitoring the chemical and textural changes during ripening of Iranian white cheese made with different concentrations of starter. Journal of Dairy Science, 89(9), 3318-3325

Lima, C.D.C., Cerqueira, M.M.O.P., Ferreira, E.G., Faria, J.C.L.L., Nelson, D.L., Carmo, L.S. and Rosa, C.A. (2008). Microbiological, physical-chemical and sensory evaluation of a traditional Brazilian cheese during the ripening process. World Journal of Microbiology and Biotechnology, 11, 2389-2395.

Longaray, D.A.P., Conte, P.A.C., Mandelli, F., Chequeller, R. and Echeverrigaray, S. (2012). Microbiological, physico-chemical and sensorial characteristics of Serrano, an artisanal Brazilian cheese. Food and Nutrition Sciences, 3(8), 10681075.

López, O.M. (2004). Mejoramiento de vida de anaquel en queso tradicional ranchero y queso de pasta hilada (Oaxaca). México. Universidad Iberoamericana. Tesis de Maestría.
Lucey, J.A., Johnson, M.E. and Horne, D.S (2003). Invited review: Perspectives on the basis of the rheology and texture properties of cheese. Journal of Dairy Science, 86(9), 2725-2743.

Norma Mexicana (NMX). (1976). Determinación de proteínas en quesos procesados. Método de prueba (NMX-F-098-1976).

Norma Oficial Mexicana (NOM). (2010). Productos y servicios. Leche, fórmula láctea, producto lácteo combinado y derivados lácteos. Disposiciones y especificaciones sanitarias. Métodos de prueba (NOM-243-SSA1-2010).

Osorio, T.J.F., Velásquez, C., José, H. and Mejía, L.G. (2005). Caracterización reológica y textural del queso Edam. Dyna, 72(147), 33-45

Pinho, O., Mendes, E., Alves, M.M. and Ferreira I. M.P.L.V.O. (2004). Chemical, physical, and sensorial characteristics of "Terrincho" ewe cheese: changes during ripening and intravarietal comparison. Journal of Dairy Science, 87(2), 246257.

Serres, L., Amariglo, S. and Petrnasxiene, D. (1973). Controle de la qualité des ProduitsLaitiers. In Analyse Physique etChimique. Ministére of I'Agruculture.Francia

Solís, M.A.D., Estrada, F.J.G. and Castelán, O.O.A. (2013). A study on the texture diversity of the artisan Ranchero cheese from central Mexico. International Journal of Dairy Technology, 66(1), 37-44

Szczesniak, A. S. (1963). Classification of textural properties. Journal Food Science, 28, 385-398.

Szczesniak, A. S. (1966). Texture measurements. Food Technology, 20, 52-58.

Tunick, M.H. and Van Hekken, D.L. (2010). Rheology and texture of commercial queso fresco cheeses made from raw and pasteurized milk. Journal of Food Quality, 33, 204-215.

Van, V.T. (1991). Terminology to be used in cheese rheology. In: Rheological and Fracture Properties of Cheese. IDF Standard 268. Brussels, Belgium. International Dairy Federation.

Vasek, O.M., Mazza, S.M. and Savoy, G.G. (2013). Physicochemical and microbiological evaluation of Corrientes artisanal cheese during ripening. Food Science and Technology (Campinas), 33(1), 151160.

Villegas, G.A. and Cervantes, E.F. (2011). La genuinidad y tipicidad en la revalorización de los quesos artesanales mexicanos. Estudios Sociales, Santo Domingo, 19(38), 145-164. 